\title{
A Bird's Eye View of Census 2011
}

\author{
P Sai Shankar \\ Department of H\&S, C.V.R College of Engineering, Ibrahimpatan, Hyderabad, India \\ E mail Id: saishankar26@gmail.com
}

\begin{abstract}
The first census was held in India during 1872. Since then, Census in India has been held uninterruptedly for every ten years. The 2011 census of India is the 15th Census and the 7th after independence. The Census plays a vital role in the study of - Demography, 'Literacy \& Education', 'Fertility and Mortality', 'Scheduled Castes and Scheduled Tribes', Migration and Economic Activity', Language and Religion. This paper compares Census 2011 with 2001 Census in the various fields of study. According to the 2011 Census data, India has a population of $\mathbf{1 2 1}$ million. It is the second highest populous country in the world. In India the population is increasing enormously, but child sex ratio and sex ratio is at an alarming stage. Inspite of it, one encouraging factor is that Literacy rate is continuously increasing from the time of Independence.
\end{abstract}

Index terms - Census Data (2001 and 2011), Demography, Literacy, Economic Activity.

\section{INTRODUCTION}

A population Census is the process of collecting, compiling and analyzing demographic, cultural, social, and economic data relating to all persons in the country. In our country census takes place once every ten years. For every ten years the Ministry of Home Affairs, Government of India will conduct the Census. The Indian Census has a strong history behind it. India is one of the country in the world, which has a remarkable history of conducting Census for every ten years. In the history 'Rig Veda' tells that during 800-600 BC there was some kind of Population count was maintained. In 321 BC, Kautilya's Arthasastra, focused on Census taking as a measure of State policy for purpose of taxation. During the period of Mughal king Akbar, they used to collect the data from the villages for collecting the taxes. After that a systematic and non synchronously population census were conducted between 1865 and 1872 in different parts of our country.But the first synchronously population census were conducted in 1881 .

Why is Census necessary?

- Demography (the statistical study of human population)

- Economic Activity

- Literacy \& Education

- Urbanization

- Fertility \& Mortality

- Language \& Religion

- To make decisions regarding public welfare

- Monitoring ongoing scheme

- Plan for future

\section{HighlightS ON 2011 CENSUS}

The Slogan of the 2011 Census - "Our Census Our Future"

\section{A. Administrative Units}

Mr. C Chandramouli is the Registrar general and Commissioner of 2011 Census. Census 2011 has covered 640 districts, 5767 Sub-districts (Tahsil), 7742 Towns, 6.41 lakh Villages and 1.2 Billion people in India. In 2011 census forms were printed in sixteen languages. The total Cost of 2011 Census is Rs.2209 Crores. i.e., Cost per person is Rs.18. In 2001 the total Cost of Census was Rs.1403 Crores i.e., Cost per person was Rs.14. In 2011 Census the total cost was increased by 806 Crores, when compared to 2001 Census .

\section{B. Population}

According to Census 2011, the population of India is 12.10 billion consisting of 6.23 billion males and 5.865 billion female populations. Comparing to 2001, the total population is 10.287 of which 5.323 billion are males and 4.965 billion are females. Interestingly, the total population of India is more than the combined population of Pakistan, U.S.A., Japan Brazil, Bangladesh and Indonesia put together. The population of India has increased by more than 1.81 billion during the decade 2001-2011, Increase among males is 91.15 million and Increase among females is 89.95 million during the decade 2001-2011. In Census 2011, In 2011 census the highest population is recorded in Uttar Pradesh with 200 million. It was the most populous State in India. Brazil country population is less than the population of Uttar Pradesh. Maharashtra and Uttar Pradesh (312 million), is greater than the population of USA.

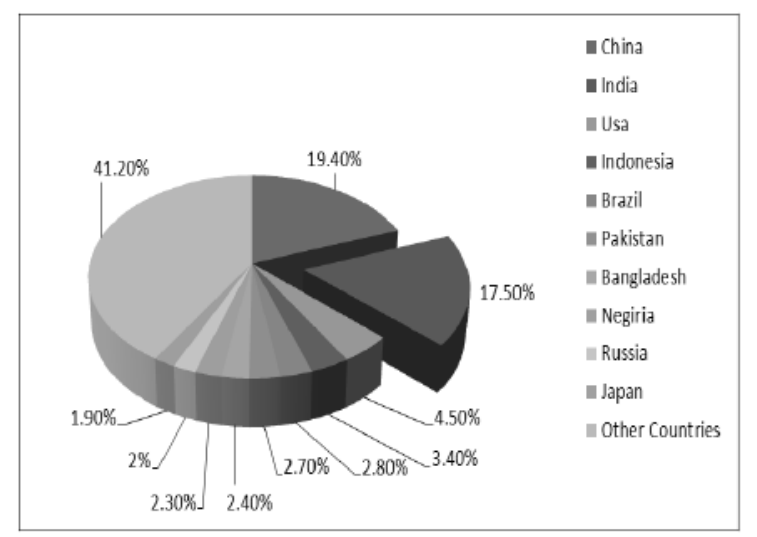

Figure 1.Population of India compare with other Countries 
From the Figure 1.we can observe that highest share of population is China (19.40\%) next is India (17.50\%). According to the U.N.O (United Nations Organization) by the end of the year 2030 India's population will crosses the China's population.

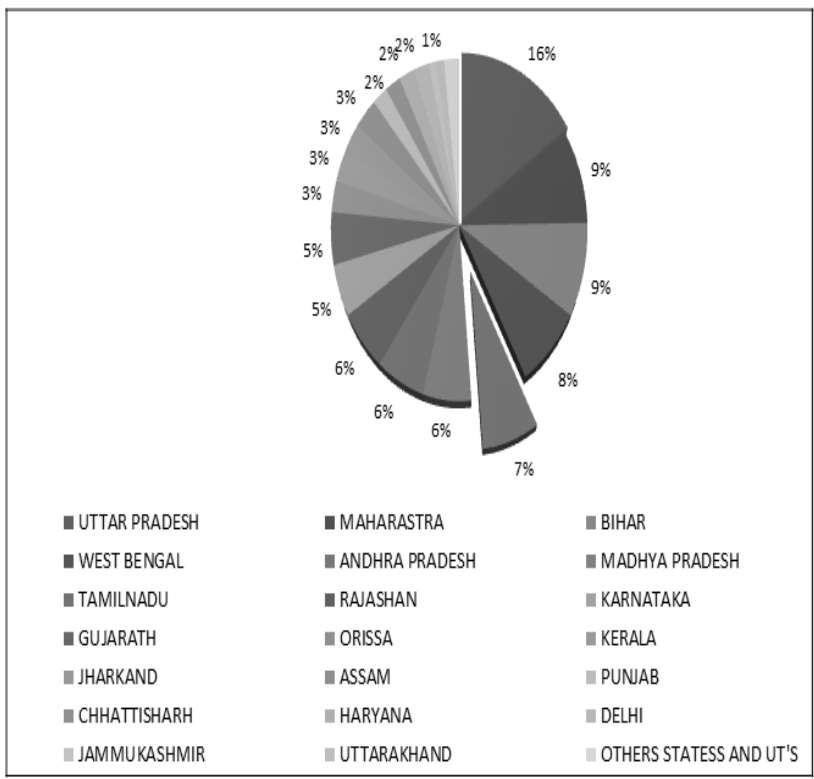

Figure 2. Population share of different states in India in 2011 census.

Figure 2. shows the highest population share is Uttar Pradesh (16\%) and Andhra Pradesh is in the fifth position (7\%). Here the population of Uttar Pradesh is more than the population of Brazil.

TABLE I

\section{SMallest ANd Highest PoPulation States/UTs IN} INDIA IN CENSUS 2011

\begin{tabular}{|c|c|}
\hline \multicolumn{2}{|c|}{ BOTTOM 5 STATES AND UTs } \\
\hline Lakshadweep(UT) & 64,429 \\
\hline & $2,42,911$ \\
\hline Daman \& Diu(UT) & $3,42,853$ \\
\hline Dadra Haveli(UT) & $3,79,944$ \\
\hline Andaman Islands(UT) & $6,07,688$ \\
\hline Sikkim(STATE) & \\
\hline
\end{tabular}

\begin{tabular}{|c|c|}
\hline \multicolumn{2}{|c|}{ TOP 5 STATES AND UTs } \\
\hline Uttar Pradesh (STATE) & $199,581,477$ \\
\hline Maharashtra(STATE) & $112,372,972$ \\
\hline Bihar(STATE) & $103,804,637$ \\
\hline West Bengal(STATE) & $91,347,736$ \\
\hline Andhra Pradesh(STATE) & $84,665,533$ \\
\hline
\end{tabular}

In absolute numbers, out of the total increase of 181 million in the last decade, the contribution of rural and urban areas is equal (91.0 million each). Maharashtra has the highest share in urban population with 50.8 million (13.5\% of the country's urban population) whereas Uttar Pradesh has the largest share in rural population at 155.3 million ( $18.6 \%$ of the country's rural population). For the first time since Independence, the increase in population is less in rural area that in urban areas.

\section{Population Growth Rate}

The rate of growth in the population in India during the year of $2001-11$ is $17.7 \%$. In that males growth rate is $17.19 \%$ and female growth rate is $18.12 \%$. Hence during 2001-11 the male's growth rate is less than the female growth rate. Since Independence (1951-61), the percentage decadal growth during 2001-11 has registered the sharpest decline in the population. During 2001-11the percentage of growth rate has decreased of 3.90 percentage points from 21.54 to 17.64 percent, but among the 28 States, Bihar (25.4\%) has registered highest decadal growth in population. The following bar chart represents the percentage of growth rate from 1951-2011 in India.

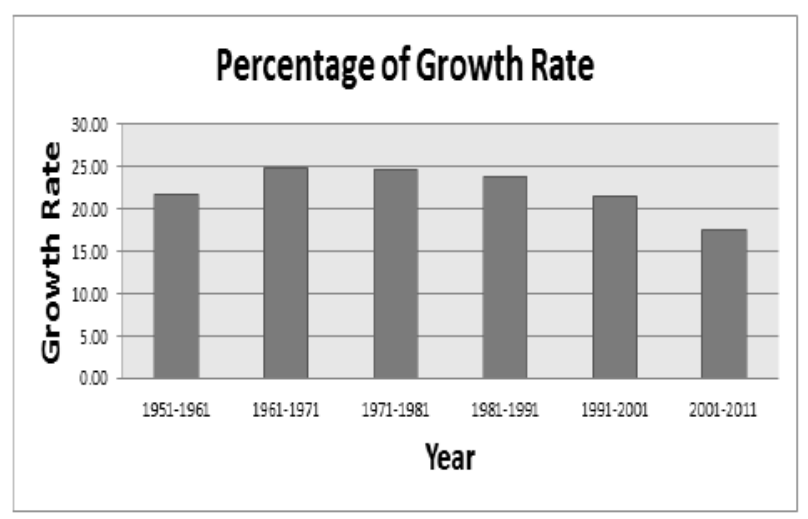

Figure 3. Growth rates from the year 1951-2011.

From the Figure 3. we can observe from 1951-81 the growth rate has been increasing. After that from 19812011 the growth rate is decreasing but compared to all the years, during 2001-11, the percentage of growth rate is less. In this period, 14 States/UTs have recorded population growth above $20 \%$.

\section{E. Population( $0-6$ years)}

In 2011 the population (0-6 years) is 158.7 million consisting of males 82.9 million and Females 75.8 million. In 2001 Census the child population is 163.8 million (Males 85 million and Females 78.8 million). The difference in child population during the period 2001-11 is -50, 48,108 (Males -20, 56, 132 and Females -29, 91, 976). Hence we can say that child population (0-6 years) is decreased during 2001-11. Uttar Pradesh (29.7 million), Bihar (18.6 million), Maharashtra (12.8 million), Madhya Pradesh (10.5 million) and Rajasthan (10.5 million) constitute more than $50 \%$ children in the age group of 0-6 years.

\section{F. Sex Ratio (Number of Females per 1000 Males)}

The sex ratio in the country which was at 940 in 2011 census. In 2011 census Sex ratio has increased by 7 points compare to 2001. This is the highest Sex Ratio recorded since 1971 Census and a shade lower than Census 1961. In rural areas in India, the sex ratio has increased from 946 to 949. The increase in urban areas has been of 29 points from 900 to 929. In Census 2011, Kerala has recorded the highest sex ratio (1084), in Rural (1078) and the 
corresponding value in Urban population (1091) respectively. The lowest sex ratio in rural areas has been recorded in Chandigarh (690) and the corresponding value in Urban areas has been recorded in Daman \& Diu (551). Three major States (Jammu Kashmir, Bihar \& Gujarat) have a decline in Sex Ratio in 2011 Census. In this Census the sex ratio in the Rural areas (947) has increased by one point when compare to 2001 (946), in Urban areas sex ratio (926) is rapidly increased as compared to 2001 (900). The important point we should notice is that in Urban areas has shown increase of 3.9 million and decline of 8.9 million children in Rural areas. The following line chart represents the sex ratio from 1951-2011.

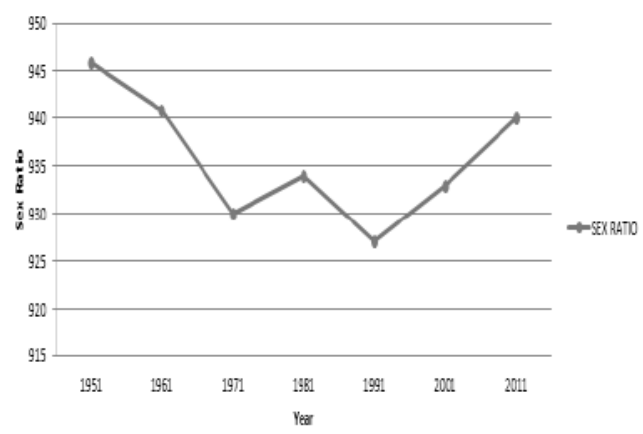

Figure 4. Sex Ratio from the years 1951-2011.

\section{G. Child Sex Ratio (0-6 years)}

In 2011 Census, child sex ratio (0-6 years) is 914. During 2001-11, child sex ratio rapidly decreased from 927 to 914 (-13 points) in the country. This is the lowest sex ratio since the year 1961. In Urban areas, the fall has been by 1 point (906 to 905) and in Rural areas, the decline has been 11 points (934 to 923) over the last decade 2001-11. In Rural areas Delhi (814) has recorded the lowest child sex ratio and Chhattisgarh (977) the highest child sex ratio during the year of 2011. In Urban areas Haryana (832) has recorded the lowest child sex ratio and Pondicherry (975) the highest child sex ratio. The following line chart represents the trends in child sex ratio from 1951-2011.

From the Figure 5.we can say that the Child Sex Ratio has been decreased from 1951-2011 Census. There will be an upward trend in the Child Sex Ratio (0-6) in Mizoram, Himachal Pradesh, Punjab, Tamil Nadu, Gujarat and Haryana,. In all remaining 27 States/UTs, the Child Sex Ratio has declining during the period 2001-11.

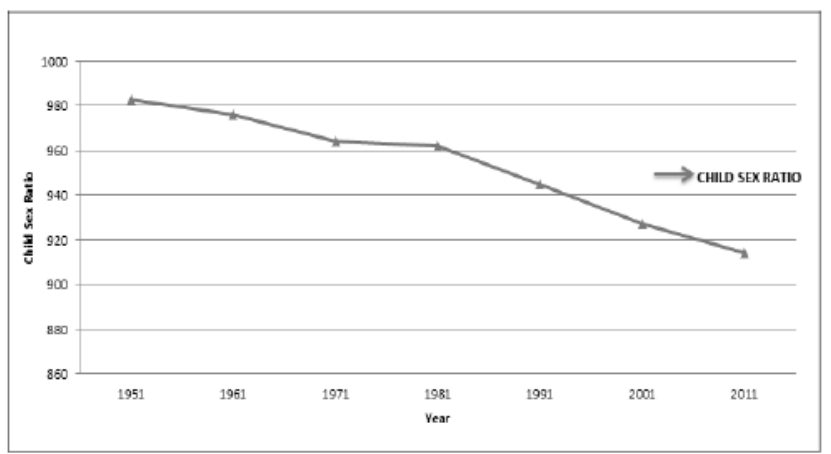

Figure 5. Growth rates from the year 1951-2011.

\section{H. Effective Literacy Rate (Population aged 7 and above)}

The Effective Literacy Rate has recorded in India in Census 2011 is $73.0 \%$. In Urban areas literacy rate is $84.1 \%$, and in Rural areas, literacy rate is $67.8 \%$. There has been a positive increase of 8.2 percentage points $(9.1$ percentage points in rural areas and 4.2 percentage points in urban areas) during the last decade 2001 -11. In 2011 the Population (aged 7 and above) is 1051 million (Males 540.7 million and Female 510.6 million). In 2001 Population (aged 7 and above) is 864 million (Males 447.2 million and female 417.6). Figure 6 shows that the literacy rate is increasing gradually since 1951 .

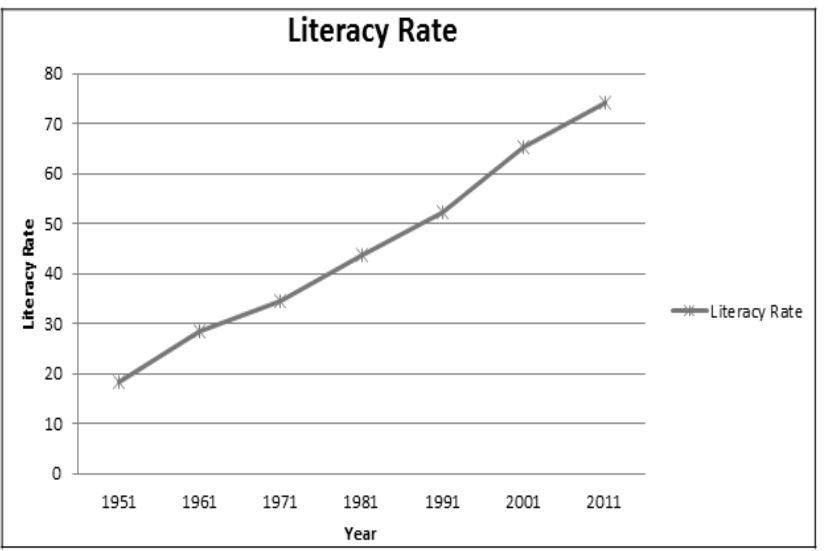

Figure 6. Litearcy rates from the year 1951-2011.

\section{(i) Male Literacy}

In 2011 Census the male Literacy rate in India is $80.9 \%$ (Rural areas $77.2 \%$ and Urban areas $88.8 \%$ ). The highest male literacy rate in Rural areas has recorded in Kerala (95.4\%), while the lowest is recorded from Arunachal Pradesh (67.4\%). In Urban areas, the lowest male literacy rate has been recorded in Uttar Pradesh $(80.4 \%)$ and the highest is in Mizoram (98.0\%).

\section{(ii) Female Literacy}

In 2011 Census the female Literacy rate in India is $64.6 \%$ (Rural areas $57.9 \%$ and Urban areas $79.1 \%$ ). The highest female literacy rate in Rural areas has recorded in Kerala $(90.8 \%)$, while the lowest has recorded in Rajasthan (45.8\%). In Urban areas, the lowest female literacy rate is returned from Jammu \& Kashmir (69.0\%) and the highest is in Mizoram (97.3\%). A significant milestone reached in Census 2011 is that a decline of 3, 11, 96, 847 among illiterates is noted. Ten States and Union Territories(U.Ts) Lakshadweep, Puducherry, Delhi, Kerala, , Goa, Tripura, , Daman \& Diu, , Chandigarh, Mizoram and Andaman \& Nicobar Islands have achieved literacy rate of above 85 per cent in 2011 Census. The important factor (Literacy rate) is continuously increasing over the period from 1951 to 2011. In 2011 census has recorded the highest literacy rate $(73 \%)$ from Independence. 


\section{Census 2011 Figures At GlanCE}

TABLE. 2

\begin{tabular}{|c|c|c|c|c|c|c|}
\hline \multirow{2}{*}{\multicolumn{2}{|c|}{ Villages }} & \multicolumn{2}{|c|}{2001} & 2011 & & \\
\hline & & 6.381 & & 6.41 lakh & & \\
\hline \multicolumn{2}{|c|}{ Towns } & \multicolumn{2}{|c|}{5161} & 7742 & & \\
\hline \multicolumn{2}{|c|}{ Tehsils } & \multicolumn{2}{|c|}{5463} & 5767 & & \\
\hline \multicolumn{2}{|c|}{ Districts } & \multicolumn{2}{|c|}{593} & 640 & & \\
\hline \multicolumn{2}{|c|}{ States \& UT } & \multicolumn{2}{|c|}{35} & \multirow{2}{*}{$\frac{35}{1.2 \text { Billion }}$} & & \\
\hline \multirow{3}{*}{\multicolumn{2}{|c|}{ people }} & \multicolumn{2}{|c|}{$\begin{array}{c}1.02 \\
\text { Billion }\end{array}$} & & & \\
\hline & & \multicolumn{3}{|c|}{ Absolute } & \multicolumn{2}{|c|}{ Percentage } \\
\hline & & Total & Rural & \multirow{2}{*}{$\begin{array}{l}\text { Urban } \\
37.7\end{array}$} & \multirow{2}{*}{$\begin{array}{l}\text { Rural } \\
68.8\end{array}$} & Urban \\
\hline \multirow{3}{*}{$\begin{array}{l}\text { Total } \\
\text { Populati } \\
\text { on }\end{array}$} & Persons & 121.0 & 83.3 & & & 31.1 \\
\hline & Males & 62.3 & 42.7 & 19.5 & 68.5 & 313 \\
\hline & Females & 58.6 & 40.5 & 18.1 & 69.1 & 30.8 \\
\hline & & \multicolumn{3}{|c|}{ Absolute } & \multicolumn{2}{|c|}{ Percentage } \\
\hline & & Total & Rural & Urban & Rural & Urban \\
\hline \multirow{2}{*}{$\begin{array}{l}\text { Decadal } \\
\text { change }\end{array}$} & Persons & 18.1 & 9.04 & 9.08 & 12.18 & 31.8 \\
\hline & Males & 9.1 & 4.6 & 4.52 & 12.12 & 30.06 \\
\hline $\begin{array}{l}2001- \\
2011\end{array}$ & Females & 8.9 & 4.4 & 4.57 & 12.25 & 33.73 \\
\hline Sex & atio & 940 & 947 & 926 & & \\
\hline Child Po & lation in & & Absolu & & Perc & tage \\
\hline $\begin{array}{r}\text { the age } \\
y\end{array}$ & oup 0-6 & Total & Rural & Urban & Rural & Urban \\
\hline & Persons & 15.8 & 11.7 & 4.1 & 14.11 & 10.93 \\
\hline & Males & 8.2 & 6.1 & 2.1 & 14.32 & 11.07 \\
\hline & Females & 7.5 & 5.6 & 1.95 & 13.9 & 10.78 \\
\hline Child & $x$ Ratio & 914 & 919 & 902 & & \\
\hline & & & Absolut & & Perc & tage \\
\hline & & $\begin{array}{c}\text { Tota } \\
1\end{array}$ & Rural & Urban & Rural & Urban \\
\hline Literates & Persons & 77.8 & 49.3 & 28.5 & 68.91 & 84.98 \\
\hline & Males & 44.4 & 28.8 & 15.6 & 78.57 & 89.67 \\
\hline & Females & 33.4 & 20.4 & 12.9 & 58.75 & 79.92 \\
\hline
\end{tabular}

\section{IV.CONCLUSIONS}

According to the census 2011 data

- India's population is 1.21 billion. In the 2011 census the country has added 181 million new people. The good news is that $17.64 \%$, the rate of growth during 2001-11 represents the sharpest decline since Independence.

- Encouraging news is that literacy rate in India is increasing continuously from the time of Independence. A significant milestone reached in Census 2011 is that a decline of 3,11,96,847 among illiterates is noted. And also female literacy rate is also improved over the decade. The following are schemes of Indian government for improvement of Literacy rate in India.

1. Operation Black Board Scheme

2. Sarva Shiksha Abhiyan
3. Computer Literacy and study schemes in Schools.

- The biggest shock in this 2011census is the decline in the child sex ratio at 914 girls for every 1000 boys. The reasons behind these trends are:

1. Son preference trend

2. Sex selection practices

3. Causes of childhood deaths

4. Rising costs of dowry.

- Another encouraging factor is Sex Ratio. In 2011 census the sex ratio in the rural is (947) is increased one point compare to 2001 (946), but in Urban areas in 2011 sex ratio (926) is rapidly increased as compared to 2001 (900). When we compare rural and urban areas in 2011, in the urban areas sex ratio is less than rural areas. The reasons behind this trends:

1. Medical facility (In urban areas sex selection abortions are high)

2. Son preference and daughter discrimination

3. Infanticide (Intentionally killing of children under age of 12 months)

\section{REFERENCES}

[1] www.mospi.com

[2] www.indiastat.com

[3] http://www.census2011.co.in/

[4] http://censusindia.gov.in/

[5] A.Malhotra and R.Pande - Son preference and Daughter neglect in India,2006

[6] Dr.Sukwanth singh - Population and Census

\section{APPENDIX}

The ratios in this paper are computed using the following formulae:

1) Population Percentage $=$ Total population of the State $\frac{\text { Total Population of a Country }}{100}$

2) Growth Rate $=(($ Current year population-Previous year population $) \times 100) \div($ Previous year population $)$.

3) Sex Ratio $=\frac{\text { Number of females }}{\text { Number of males }} \times 1000$

4) Child Sex Ratio in age group 0-6 year =

$\{(($ Total Number of female children in age group 0-6 years $))$ $\times 1000) \div($ Total Number of male children in age group $0-6$ years) $\}$

5) Effective Literacy rate of population is defined as the percentage of literate persons whose age is 7 and above and who can both write and as well as read in any language has been consider as literate to the total population aged 7 and above.

Effective Literacy Rate $=$

((Total Number of Literate people whose age is 7 and above) $\times 100) \div($ Total Population of age group 7 and above $))$ 